\title{
Zmiana i uchylenie aktów administracyjnych organów Unii Europejskiej - modele teoretyczny i normatywny
}

\section{Uwagi wstępne}

Jednostki często planują swoje działania na podstawie aktów administracyjnych, ich zmiana lub uchylenie może więc spowodować naruszenie uzasadnionych oczekiwań ${ }^{2}$ Z tego powodu muszą obowiązywać rozwiązania prawne ograniczające możliwość pozbawienia jednostki praw nabytych na podstawie aktów administracyjnych ${ }^{3}$. Jednakże w prawie pisanym Unii Europejskiej brak jest uniwersalnych reguł dotyczących zagadnienia wzru-

1 Dr Łukasz Prus, Zakład Porównawczej Administracji Publicznej, Instytut Nauk Administracyjnych, Uniwersytet Wrocławski.

$2 \mathrm{~W}$ ostatnim czasie model ReNEUAL stanowił inspirację do pogłębionych analiz problematyki wzruszalności ostatecznych aktów administracyjnych, zob. J.-P. Schneider, The ReNEUAL codification project - book III [w:] The model rules on EU administrative procedures: adjudication, M. Ruffert (ed.), Groningen 2016, s. 12-13; M. Kamiński, Zmiana i uchylenie decyzji niewadliwych $i$ wadliwych $w$ świetle założeń modelu kodeksu postępowania administracyjnego Unii Europejskiej. Uwagi na tle niemieckiej federalnej ustawy o postępowaniu administracyjnym, s. 349; P. Rączka, T. Jędrzejewski, Zmiana i uchylenie decyzji w modelu kodeksu postępowania administracyjnego Unii Europejskiej w kontekście polskich doświadczeń, s. 323; M. Baran, Zmiana i uchylenie decyzji: dotychczasowa praktyka a propozycje zawarte $w$ modelu kodeksu postępowania administracyjnego Unii Europejskiej (wybrane problemy), s. 305 oraz P. Kledzik, Weryfikacja aktów administracyjnych według założeń modelu kodeksu postępowania administracyjnego Unii Europejskiej $w$ kontekście uregulowań kodeksu postępowania administracyjnego, s. 331 - wszystkie w: Kodeks postępowania administracji Unii Europejskiej, J. Supernat, B. Kowalczyk (red.), Warszawa 2017.

3 Przez uchylenie aktu administracyjnego (ang. withdrawal of administrative act) należy rozumieć całkowite zniesienie skutku prawnego (mocy obowiązującej) ostatecznego aktu administracyjnego. Natomiast przez zmianę aktu administracyjnego (ang. amend/rectification of administrative act) należy rozumieć modyfikację tylko pewnych aspektów materialnych aktu administracyjnego, których nie można zaliczyć do oczywistych omyłek podlegających sprostowaniu, P. Craig, G. della Cananea, O. Mir, J.-P. Schneider, V.M. Tünsmeyer, M. Wierzbowski, Wydawanie decyzji w sprawach indywidualnych [w:] ReNEUAL. Model kodeksu postępowania administracyjnego Unii Europejskiej, M. Wierzbowski, H.C.H. Hofmann, J.-P. Schneider, J. Ziller (red.), M. Wierzbowski (red. wyd. polskiego), A. Kraczkowski, tłum. M. Ziental, P. Dorobek, Warszawa 2015, s. 141. 
szalności ostatecznych aktów administracyjnych ${ }^{4}$. Z jednej strony kwestię tę regulują zasady wypracowane przez relewantne orzecznictwo Trybunału Sprawiedliwości Unii Europejskiej (TSUE), które nie są wynikiem działań legislacyjnych, lecz wyrazem potrzeby wypełnienia luki w prawie i stworzenia kryteriów (wzorców) kontroli sądowej tej szczególnej działalności administracji unijnej. $\mathrm{Z}$ drugiej strony funkcjonuje model normatywny przyjęty w postępowaniu administracyjnym UE, opracowany przez sieć naukowo-badawczą do spraw prawa administracyjnego UE (Research Network on EU Administrative Law - ReNEUAL) ${ }^{5}$. Warto więc przeprowadzić rekonstrukcję, systematyzację i konceptualizację elementów istotnych dla zasad wzruszenia aktów administracyjnych wynikających z kazuistycznego prawa sędziowskiego TSUE, ponieważ w ten sposób można wypracować model teoretyczny zmiany lub uchylenia aktów administracyjnych UE. Istotne jest również porównanie obu modeli, tj. teoretycznego i normatywnego, zmiany lub uchylenia aktów administracyjnych organów administracji unijnej ${ }^{6}$.

Przyjęty cel badawczy determinuje sposób prowadzenia rozważań. W pierwszej kolejności zostanie skonstruowany model teoretyczny, a następnie omówiony model normatywny przedstawiony przez sieć ReNEUAL. $\mathrm{W}$ ramach każdego $\mathrm{z}$ tych modeli analizowane będą te same relewantne sytuacje, podzielone według kryterium legalności i skutku prawnego aktu administracyjnego dla jego adresata. Tak więc najpierw zostaną zbadane

4 M. Niedźwiedź, Administracyjne wykonywanie prawa Unii Europejskiej [w:] System Prawa Administracyjnego, t. 3, Europeizacja prawa administracyjnego, R. Hauser, Z. Niewiadomski, A. Wróbel (red.), Warszawa 2014, s. 139. Mimo braku jednolitych przepisów unijnych regulujących nadzwyczajne tryby zmiany lub uchylenia aktów administracyjnych $\mathrm{w}$ prawie wtórnym można odszukać fragmentaryczne przepisy normujące tę procedurę w szczególnych postępowaniach sektorowych, zob. J. Schwarze, European administrative law, Luxemburg 1992, s. 980 i n. W aktualnym stanie prawnym zob. art. 6 ust. 3 lit. a rozporządzenia Rady nr 139/2004 z dnia 20 stycznia 2004 r. w sprawie kontroli koncentracji przedsiębiorstw (Dz.Urz. UE L 24, s. 1); art. 9 ust. 2 rozporządzenia Rady (WE) nr 1/2003 z dnia 16 grudnia 2002 r. w sprawie wprowadzenia w życie reguł konkurencji ustanawianych w art. 81 i 82 Traktatu (Dz. Urz. UE L 1, s. 1).

5 Trzeba jednak zauważyć, że zadaniem sieci naukowo-badawczej ReNEUAL było opracowanie reguł wzorcowych postępowania administracyjnego dla organów administracji unijnej poprzez zebranie w nowym akcie prawnym wszystkich zasad rozproszonych w obowiązujących przepisach UE oraz orzecznictwie TSUE, przy jednoczesnej modyfikacji istniejących reguł, o ile istnieje taka potrzeba. Innymi słowy, grupa uczonych podjęła się próby kodyfikacji rozproszonego case law i fragmentarycznych procedur sektorowych. Tym samym model normatywny zbliża się do modelu naukowego. Niemniej jednak model opracowany przez sieć naukowo-badawczą ReNEUAL nie jest prostą średnią arytmetyczną dotychczasowych doświadczeń prawnych TSUE, lecz wprowadza pewne innowacyjne i nieznane rozwiązania prawne.

6 Model teoretyczny ograniczam tylko do modelu przepisów ReNEUAL. Z uwagi na ograniczenia techniczne poza polem podjętej analizy pozostaje np. projekt wniosku w sprawie postępowania administracyjnego instytucji, organów i jednostek organizacyjnych Unii Europejskiej z 2016 r. 
reguły uchylenia lub zmiany zgodnych z prawem korzystnych aktów administracyjnych. Następnie przedmiotem analizy będzie uchylenie lub zmiana niezgodnych z prawem aktów administracyjnych, które przyznają pewne korzyści stronie. W końcu zaś zostaną omówione reguły zmiany lub uchylenia aktów administracyjnych nakładających obowiązki na strony (decyzji niekorzystnych). W każdym z tych przypadku zostanie rozważony temporalny skutek zmiany lub uchylenia aktów administracyjnych. Ostatecznym wynikiem porównania będzie ustalenie tożsamości i różnic między tymi modelami, co może stanowić pewien punkt odniesienia w pracach nad przyszłym rozporządzeniem Parlamentu Europejskiego i Rady regulującym postępowanie przed organami administracji unijnej ${ }^{7}$.

\section{Model teoretyczny}

\subsection{Zmiana i uchylenie zgodnych z prawem korzystnych dla strony aktów administracyjnych}

W sprawach Algera $^{8}$ i SNUPAT ${ }^{9}$ Trybunał wyjaśnił, że co do zasady nie jest dopuszczalna zmiana lub uchylenie zgodnego z prawem aktu administracyjnego, który przyznaje prawa podmiotowe/indywidualne lub inne korzyści (ang. legal measure which has conferred individual rights/subjective rights or similar benefits). Skoro prawo zostało przez jednostkę nabyte, to konieczność zapewnienia zaufania do stabilności jej sytuacji prawnej przeważa nad interesem administracji zmierzającej do wzruszenia aktu administracyjnego ${ }^{10}$.

7 Powyższa metodologia inspirowana jest modelem badań porównawczych autorstwa F. Longchampsa, zgodnie którym w pierwszej kolejności należy wyznaczyć przedmiot badań w krajach $A, B, C \ldots$, którym jest zjawisko prawne odpowiadające apriorycznej definicji $d$; w kolejnej fazie w każdym ze zjawisk prawnych bada się jego przypuszczalne cechy pozadefinicyjne $f, g, h \ldots$ i stwierdza się różnice między nimi, $\mathrm{w}$ końcu następuje wynik porównania, F. Lonchamps, Z badań porównawczych w dziedzinie prawa. Refleksja metodologiczna, "Acta Universitatis Wratislaviensis”, No 125, Prawo XXXII, Wrocław 1970, s. 130-132.

8 Wyrok TSUE z dnia 12 lipca 1957 r. w sprawach połączonych 7/56, 3-7/57, Dinecke Algera $i$ inni v. Wspólne Zgromadzenie Europejskiej Wspólnoty Wegla i Stali, ECR 1957, s. 0081, ECLI:EU:C:1957:7.

9 Wyrok TSUE z dnia 22 marca 1961 r. w sprawach połączonych 42/59 i 49/59, Société Nouvelle des Usines de Pontlieue - Aciéries du Temple (SNUPAT) v. Wysoka Władza Europejskiej Wspólnoty Węgla i Stali, ECR 1961, s. 00103, ECLI:EU:C:1961:5.

10 W sprawie Lagardère i Canal+ Sąd orzekł, że uchylenie zgodnych z prawem aktów administracyjnych przyznających prawa podmiotowe lub inne korzyści jest sprzeczne z zasadami ogólnymi europejskiego prawa administracyjnego. „In the absence of specific provisions in the Treaty or in the relevant secondary law, the general principles of Community law have been taken by the Court of Justice and the Court of First Instance as the basis for developing the criteria in accordance with which the Community institutions may revoke, with retrospective effect, favourable Community 
W doktrynie zwrócono jednak uwagę, że nie jest jasne, co należy rozumieć przez to, że akt administracyjny przyznaje prawa podmiotowe/indywidualne ${ }^{11}$. Niektórzy przedstawiciele doktryny argumentowali, że w tym względzie Trybunał powinien postępować zgodnie z francuskimi standardami cofnięcia (fr. retrait) aktów administracyjnych. Według tej koncepcji o tym, czy ostateczny akt administracyjny jest wzruszalny czy też nie decyduje charakter kompetencji organu administracji publicznej i stopień jego związania przez normę kompetencyjną. Zgodnie z tym modelem decyzje konstytutywne (uznaniowe) nie podlegają cofnięciu. Natomiast decyzje deklaratywne (związane), które nie tworzą (kreują) nowej sytuacji prawnej, mogą być przedmiotem cofnięcia ${ }^{12}$.

Inni przedstawiciele doktryny twierdzą, że Trybunał powinien stosować reguły znane w niemieckim, holenderskim i skandynawskim prawie administracyjnym, zgodnie z którymi o uchyleniu przesądza skutek aktu administracyjnego, a nie charakter kompetencji organu czy też jego związanie normą kompetencyjną. Zatem akt administracyjny będzie niewzruszalny, jeżeli przyznaje jakiekolwiek korzyści jednostce, natomiast jeśli nakłada na nią obowiązki, może zostać uchylony lub zmieniony ${ }^{13}$.

W literaturze przyjmuje się, że pewnych wyjaśnień w tym sporze dostarcza wyrok w sprawie de Compte ${ }^{14}$. Rozpoznając tę sprawę, Trybunał wyjaśnił, że uzasadnione oczekiwanie co do legalności korzystnego aktu administracyjnego (ang. favourable administrative act) raz nabyte nie może być następnie podważone ${ }^{15}$. S. Schonberg, interpretując ten wyrok, zwrócił uwage, że Trybunał nie odwołał się do francuskiej terminologii i podziału na akty administracyjne konstytutywne (uznaniowe) oraz deklaratoryjne (związane). Zamiast tego Trybunał stwierdził, że zasada ustanowiona w sprawie Algera dotyczy uchylenia korzystnych aktów administracyjnych. Trybunał przyjął rozwiązanie niemieckie, holenderskie i skandynawskie. Tak więc zgodny z prawem akt administracyjny, który jest korzystny dla jego adresata, nie może zostać odwołany. Nie ma przy tym znaczenia, czy decyzja ma charakter związany (deklaratywny) czy uznaniowy (konstytu-

acts. In this connection it must be observed that, in general, the retroactive withdrawal of a legal measure which has conferred individual rights or similar benefits is contrary to the general principles of law", wyrok Sądu z dnia 20 listopada 2002 r., w sprawie T-251/00, Lagardère SCA i Canal+SA v. Komisja Wspólnot Europejskich, ECR 2002, s. II-04825, ECLI:EU:T:2002:278, pkt 138-139.

11 Skądinąd sądy UE podobnie orzekały $\mathrm{w}$ innych sprawach, stosując przy tym różne zwroty językowe, aby uchwycić kryterium zakazu odwołania aktu administracyjnego P. Craig, EU administrative law, Oxford 2012, s. 556-557.

12 S. Schonberg, Legitimate expectations in administrative law, Oxford 2003, s. 72.

13 Ibidem.

14 Ibidem, s. 72-73; P. Craig, EU administrative law..., s. 557.

15 Wyrok TS z dnia 17 kwietnia 1997 r. w sprawie C-90/95 P, Henri de Compte v. Parlament Europejski, ECR 1997, s. I-01999, ECLI:EU:C:1997:198, pkt 35-39. 
tywny) ${ }^{16}$. Jednocześnie P. Craig podkreśla, że sądy unijne stosują szeroką wykładnię pojęcia korzystnych aktów administracyjnych, odwołując się do kryterium aktów administracyjnych przyznających jednostce prawa lub inne korzyści ${ }^{17}$. Nie chodzi zatem wyłącznie o akty administracyjne przyznające prawa podmiotowe, lecz również o wszelkie ich skutki prawne, które korzystnie mogą oddziaływać na sytuację prawną jednostki.

$\mathrm{W}$ tym miejscu należy przejść do omówienia zakresu temporalnego opisanego zakazu i przesłanek wzruszenia tego rodzaju aktów administracyjnych. Korzystne akty administracyjne, które są zgodne z prawem, tylko wyjątkowo mogą być zmienione lub uchylone ze skutkiem retroaktywnym (ex tunc) lub prospektywnym (ex nunc), o ile zostały spełnione prawnie doniosłe przesłanki ${ }^{18}$. Regułą jest zatem, że zgodny z prawem akt administracyjny, który przyznaje prawa podmiotowe lub inne korzyści, nie może być odwołany $^{19}$. Powstaje jednak pytanie, czy istnieją wyjątki od tej zasady? Innymi słowy, kiedy zgodny z prawem i korzystny akt administracyjny może być wyeliminowany z obrotu prawnego? Po pierwsze, w prawie administracyjnym UE przyjmuje się, że zmiana lub uchylenie aktu administracyjnego są możliwe w przypadku i zakresie, $\mathrm{w}$ jakim wynika to wprost $\mathrm{z}$ przepisu, który zawiera wyraźną podstawę do jego wzruszenia. W takiej sytuacji akt administracyjny nie tworzy ostatecznie nabytych praw ${ }^{20}$. Po drugie, jest rzeczą niebudzącą najmniejszych wątpliwości, że zgodny z prawem akt administracyjny może być w każdym czasie uchylony za wyraźną zgodą jego

16 S. Schonberg, Legitimate expectations..., s. 73, podobnie P. Craig, EU administrative law..., s. 557. Inaczej J. Schwarze, European administrative law..., s. 970-972.

17 P. Craig, EU administrative law..., s. 557.

18 Odnośnie do zmiany lub uchylenia ze skutkiem retroaktywnym (ex tunc) zob. wyrok Sądu z dnia 20 listopada 2002 r. w sprawie T-251/00, Lagardère SCA i Canal+ SA, pkt 139. Co się zaś tyczy zmiany lub uchylenia ze skutkiem prospektywnym (ex nunc) zob. J. Schwarze, European administrative law..., s. 988; J. Ratio, The principle of legal certainty in EC Law, Dordrecht/Boston/London 2003, s. 229.

19 P. Craig, EU administrative law..., s. 557.

20 Zob. H.C.H. Hofmann, G.C. Rowe, A.H. Türk, Administrative law..., s. 179. Chodzi tu przede wszystkim o dawny art. 65 zdanie drugie Traktatu EWWiS, zastąpiony przez przepis art. 9 ust. 2 rozporządzenia Rady (WE) nr 1/2003 z dnia 16 grudnia 2002 r. w sprawie wprowadzenia w życie reguł konkurencji ustanowionych w art. 81 i 82 Traktatu, który stanowi, że Komisja może, działając z urzędu lub na wniosek, wznowić postępowanie: a) jeżeli nastąpiła istotna zmiana odnośnie do jakiegokolwiek faktu, który był podstawą do podjęcia decyzji; b) jeżeli zainteresowane przedsiębiorstwo działa wbrew swoim zobowiązaniom; c) jeżeli decyzja została podjęta w oparciu o niekompletne, nieprawdziwe lub wprowadzające w błąd informacje dostarczone przez strony. Zgodnie z art. 6 ust. 3 lit. a rozporządzenia Rady nr 139/2004 z dnia 20 stycznia 2004 r. w sprawie kontroli koncentracji przedsiębiorstw (Dz. Urz. UE L nr 24, s. 1) Komisja może odwołać swoją decyzję podjętą zgodnie z ust. 1 lit. a lub b, w przypadku gdy decyzję podjęto w oparciu o nieprawidłowe informacje, za które odpowiedzialne jest jedno $\mathrm{z}$ przedsiębiorstw lub które zostały uzyskane $\mathrm{w}$ wyniku oszustwa lub zainteresowane przedsiębiorstwa naruszyły zobowiązanie załączone do decyzji. 
adresata. Powyższe stwierdzenie nie powinno zaskakiwać, ponieważ ochrona uzasadnionych oczekiwań jednostki nie wymaga, aby akt administracyjny pozostawał $\mathrm{w}$ obrocie prawnym wbrew woli jego adresata ${ }^{21}$. Po trzecie, P. Craig, omawiając reguły uchylenia zgodnych z prawem decyzji administracyjnych, odwołuje się do przypadku, gdy akt został wydany w wyniku podstępu lub oszustwa ${ }^{22}$. Nie ma bowiem żadnego uzasadnienia przemawiającego za ochroną oczekiwań opartych na umyślnym wprowadzeniu w błąd organu w celu uzyskania korzystnego aktu administracyjnego. Wręcz przeciwnie, administracja jest obowiązana skorygować stan wywolany podstępem ${ }^{23}$. Jednostka nie może przecież czerpać korzyści ze swego bezprawia (łac. de sua malitia nemo debet commodum reportare). Zmiana lub uchylenie aktu administracyjnego może także nastąpić, jeżeli został on wydany na podstawie nieprawdziwych lub niekompletnych informacji ${ }^{24}$. Jednak według P. Craiga istnieje niebezpieczeństwo utożsamiania podstępu i oszustwa z nieumyślnym przedstawieniem błędnej informacji przez stronę 25 . Różnica pomiędzy wyłudzeniem korzystnego aktu administracyjnego a jego oparciem na niepełnych lub nieprawdziwych informacjach sprowadza się do świadomości wnioskodawcy. W pierwszej sytuacji beneficjent działa podstępnie, gdy umyślnie wprowadza w błąd organy administracji UE. W drugiej sytuacji wnioskodawca nieumyślnie (nieświadomie) udziela niepełnych lub nieprawdziwych informacji. Stąd też w doktrynie postuluje się, aby nieumyślność była istotnym czynnikiem branym pod uwagę w procesie wyważania interesu publicznego i uzasadnionych oczekiwań przy podejmowaniu decyzji o odwołaniu aktu administracyjnego opartego na nieprawdziwych lub niekompletnych informacjach ${ }^{26}$. Wątpliwości wzbudza jednak zaliczenie tego przypadku do procedur związanych $\mathrm{z}$ uchyleniem zgodnych z prawem aktów administracyjnych, skoro został on wydany na skutek celowego wyłudzenia korzystnego aktu administracyjnego. Powyższe wnioski należy skonfrontować z modelem normatywnym.

Omówione przypadki są stosunkowo proste i dobrze znane. Podjęta problematyka staje się bardziej złożona, gdy podstawą wzruszenia aktu administracyjnego będzie zmiana sytuacji prawnej, faktycznej lub polity-

21 P. Craig, EU Administrative law..., s. 558; S. Schonberg, Legitimate Expectation..., s. 79.

22 P. Craig, EU Administrative law..., s. 558.

23 Ibidem.

24 W orzecznictwie podkreśla się, że szczególnie istotną rolę odgrywają informacje przedstawione przez wnioskodawcę $\mathrm{w}$ postępowaniach o przyznanie pomocy w ramach funduszy strukturalnych, wyrok Sądu z dnia 28 stycznia 2004 r. w sprawie T-180/01, Euroagri SRL v. Komisja Wspólnot Europejskich, ECR 2004, s. II-00369, ECLI:EU:T:2004:26, pkt 87.

25 P. Craig, EU Administrative law..., s. 558.

26 Zob. J. Schwarze, European administrative law..., s. 1014; P. Craig, EU administrative law..., s. 558; S. Schonberg, Legitimate expectation..., s. 80. 
ki administracyjnej ${ }^{27}$. W pierwszym przypadku regułą jest, że zmiana lub uchylenie pierwotnego aktu administracyjnego, który był zgodny z poprzednio obowiązującym prawem, dokonana na podstawie nowego prawa, narusza prawa nabyte strony.

W drugim przypadku wzruszenie aktu administracyjnego może nastąpić w przypadku kwalifikowanej zmiany sytuacji faktycznej. Chodzi o tzw. decyzje warunkowe. Decyzja administracyjna może zostać odwołana, gdy jej skutek prawny został zastrzeżony pod warunkiem. Akt administracyjny, którego skutek jest uzależniony od zaistnienia zdarzenia przyszłego, nie staje się zatem nieodwołalny dopóki warunek nie zostanie spełniony ${ }^{28}$. Tego rodzaju akty administracyjne najczęściej są wydawane w sprawach o przyznanie środków $\mathrm{z}$ funduszy UE. Akt administracyjny może wprost zastrzegać jeden lub więcej obowiązków, od których zależy jego skutek. Problem ten dobrze ukazuje sprawa Zuckerfabrik Franken, gdzie Trybunał stwierdził, że dopłaty do dostaw cukru mogą zostać odzyskane (retroaktywnie wzruszenie aktu administracyjnego), jeżeli okaże się, że nabywca nie używa cukru do karmienia zwierząt, zgodnie z wymogami decyzji o przyznaniu dotacji $i^{29}$.

P. Craig zwraca uwagę na linię orzeczniczą zapoczątkowaną wyrokiem $\mathrm{w}$ sprawie Interhotel-Sociedade. W tym przypadku wnioskodawca otrzymał dotację z Europejskiego Funduszu Społecznego na kształcenie zawodowe. Procedura przyznawania tego rodzaju pomocy polegała na zatwierdzeniu wniosku przez Komisję i wypłacie zaliczki. Pozostała część była wypłacana po zakończeniu zadania oraz weryfikacji wykonania warunków pomocy. W tej sprawie Komisja odmówiła wypłaty pełnej kwoty, ponieważ niektóre wydatki nie zostały wymienione w zatwierdzonym wniosku, a inne nie zostały odpowiednio udokumentowane. Sąd wyjaśnił, że beneficjent pomocy finansowej, co do której Komisja zatwierdzała wniosek, nie nabywa żadnych ostatecznych praw do wypłacenia całej kwoty pomocy, jeżeli nie przestrzega jej warunków. Prawo domagania się wypłaty pełnej kwoty pomocy powstaje dopiero $\mathrm{w}$ chwili wykonania warunków zastrzeżonych $\mathrm{w}$ decyzji $^{30}$. Niezbędne jest jednak, aby beneficjent miał możliwość zapoznania się

27 S. Schonberg, Legitimate expectation..., s. 81; M. Baran, Zmiana i uchylenie decyzji: dotychczasowa praktyka..., s. 310-312.

28 P. Craig, EU Administrative law..., s. 558.

29 Wyrok TSUE z dnia 15 maja 1984 r. w sprawie 121/83, Zuckerfabrik Franken GmbH v. Hauptzollamt Würzburg, ECR 1984, s. 2039, ECLI:EU:C:1984:175. Warto też zwrócić uwagę na prawo pisane. Zgodnie z art. 7 ust. 2 rozporządzenia Rady (WE) nr 659/1999 z dnia 22 marca 1999 r. ustanawiającego szczególne zasady stosowania art. 108 Traktatu o Funkcjonowaniu Unii Europejskiej (Dz. Urz. WE L 83, s. 1) Komisja może do tzw. decyzji pozytywnej załączyć warunki, na jakich pomoc może zostać uznana za zgodną ze wspólnym rynkiem i może ustanowić obowiązki umożliwiające monitorowanie zgodności z decyzją (tzw. decyzja warunkowa).

30 Zob. wyrok Sądu z dnia 15 września 1998 r. w sprawie T-142/97, Eugénio Branco $L d^{a}$ v. Komisja Wspólnot Europejskich, ECR 1998, s. II-03567, ECLI:EU:T:1998:210 
z warunkami udzielonej pomocy. Sąd zwrócił uwagę, że w tym konkretnym przypadku ocena Komisji dotycząca zakwalifikowania wnioskowanych wydatków nie została doręczona skarżącym przed zakończeniem zadania. Nie można więc przyjąć, że beneficjent nie wykonał obowiązków wynikających z decyzji, albowiem warunki udzielenia pomocy nie zostały mu nigdy przedstawione. Innymi słowy, Komisja nie może się powołać na niewykonanie warunków, które nie zostały notyfikowane beneficjentowi. Jeżeli Komisja nie podejmuje niezbędnych środków ostrożności, aby upewnić się, czy beneficjent jest poinformowany o warunkach zastrzeżonych w decyzji zatwierdzającej wniosek, nie może zasadnie oczekiwać ich przestrzegania. W tych okolicznościach, niezależnie od tego, że przepis prawa nie wymagał przekazania beneficjentom takich informacji, Sąd stwierdził naruszenie zasady uzasadnionych oczekiwań jednostki, ponieważ wnioskodawca nie był w stanie określić warunków przyznania pomocy ${ }^{31}$. Tak więc ochrona uzasadnionych oczekiwań wymaga, aby warunki przyznanej pomocy były przedstawione beneficjentowi w taki sposób, aby mógł zapoznać się ze zobowiązaniami wynikającymi z decyzji zatwierdzającej.

W końcu powstaje pytanie, czy ostateczny akt administracyjny może być zmieniony lub uchylony $\mathrm{z}$ uwagi na zmianę polityki administracyjnej (trzeci z wymienionych przypadków). Organ administracji UE może mieć przecież racjonalne powody do zmiany przyjętej przez siebie polityki ${ }^{32}$. Na przykład może być tak, że licencja na import cukru spoza UE zostanie przyznana na rok. Jednak Komisja w świetle nowej polityki może próbować odwołać te zezwolenie. W orzecznictwie dotychczas nie podjęto tego problemu. W doktrynie jednoznacznie przyjmuje się, że zgodny z prawem, korzystny i bezwarunkowy akt administracyjny nie może być odwołany tylko z powodu zmiany polityki administracyjnej ${ }^{33}$.

\subsection{Zmiana i uchylenie niezgodnych z prawem korzystnych dla strony aktów administracyjnych}

Zmiana lub uchylenie z mocą wsteczną niezgodnych z prawem aktów administracyjnych są co do zasady dopuszczalne, o ile interes publiczny przeważa nad interesem indywidualnym, a ze skutkiem prospektywnym

pkt 97; wyrok TSUE z dnia 26 września 2008 r. w sprawach połączonych C-383/06 do C-385/06, Vereniging Nationaal Overlegorgaan Sociale Werkvoorziening i inni, ECR 2008, s. I-01561, ECLI:EU:C:2008:165, pkt 56; wyrok Sądu z dnia 30 czerwca 2005 r. w sprawie T-347/03, Eugénio Branco Ld $d^{a}$ v. Komisja Wspólnot Europejskich, ECR 2005, s. II-02555, ECLI:EU:T:2005:265, pkt 92 i 106.

31 Wyrok Sądu z dnia 14 lipca 1997 r. w sprawie T-81/95, Interhotel-Sociedade v. Komisja Wspólnot Europejskich, ECR 1997, s. II-01265, ECLI:EU:T:1997:117, pkt 49-59; P. Craig, EU Administrative law..., s. 560.

32 Zob. S. Schonberg, Legitimate expectations..., s. 86.

33 Ibidem; P. Craig, EU administrative law..., s. 560-561. 
jest to zawsze możliwe i nie podlega żadnym rygorom ${ }^{34}$. P. Craig postuluje jednak, aby także w przypadku wzruszenia aktów administracyjnych ze skutkiem ex nunc sądy unijne dokonywały wyważenia interesu publicznego i indywidualnego ${ }^{35}$. Nie ma przecież żadnego uzasadnienia, aby reguły odwołania ze skutkiem wstecznym korzystnych i niezgodnych z prawem aktów administracyjnych nie miały zastosowania również do prospektywnego wzruszenia tego rodzaju aktów. Każdorazowo należy zatem rozważyć, czy pierwotny, niezgodny z prawem akt administracyjny doprowadził do powstania uzasadnionych oczekiwań jednostki oraz czy jego prospektywne wzruszenie nastąpiło $\mathrm{w}$ rozsądnym terminie ${ }^{36}$. Konieczność zapewnienia należytej ochrony uzasadnionych oczekiwań jednostki jest uzasadniona również tym, że zmiana lub uchylenie ze skutkiem na przyszłość niezgodnego z prawem aktu administracyjnego korzystnego dla strony, bez jednoczesnego uwzględnienia interesu indywidualnego, może prowadzić do odpowiedzialności odszkodowawczej UE ${ }^{37}$.

Przechodząc zaś do przesłanek wzruszenia, należy podkreślić, że zmiana lub uchylenie niezgodnego z prawem aktu administracyjnego, który korzystnie wpływał na sytuację strony, może mieć miejsce pod warunkiem przestrzegania przez organ administracji unijnej wymogów związanych z dotrzymaniem rozsądnego terminu i ochroną uzasadnionych oczekiwań adresata $\mathrm{aktu}^{38}$. Jeśli te przesłanki nie zostaną spełnione, zostanie naruszona zasada uzasadnionych oczekiwań jednostki ${ }^{39}$. Jednakże ochrona uzasadnionych oczekiwań nie jest zasadą absolutną i bywa ograniczana z uwagi na zasadę legalności. W przypadku zmiany lub uchylenia niezgodnych z prawem i korzystnych aktów administracyjnych w sposób wyraźny konkurują ze sobą dwa sprzeczne interesy. $Z$ jednej strony interes publiczny wymaga zapewnienia legalności działania administracji unijnej. Ponadto uchylenie aktów administracyjnych może być uzasadnione tym, że ich niezgodność z prawem wpływa na sytuację prawną osób trzecich i zaburza równe trak-

34 Zob. H.C.H. Hofmann, G.C. Rowe, A.H. Türk, Administrative law and policy of the EU, Oxford 2011, s. 173; Ł. Prus, Zasada pewności i ochrony uzasadnionych oczekiwań [w:] Prawo administracyjne Unii Europejskiej, R. Grzeszczak, A. Szczerba-Zawada (red.), Warszawa 2016, s. 218.

35 P. Craig, EU Administrative law..., s. 566.

36 Ibidem, s. 567.

37 J. Raitio, The principle of legal certainty..., s. 239-240.

38 Wyrok Sądu do spraw Służby Publicznej z dnia 11 września 2008 r. w sprawie F-51/07, Philippe Bui Van v. Komisja Wspólnot Europejskich, ECLI:EU:F:2008:112, pkt 51; wyrok Sądu z dnia 16 maja 2007 r. w sprawie T-324/04, F v. Komisja Wspólnot Europejskich, ECLI:EU:T:2007:140, pkt 159, 164-166, 170. Zob. J. Lemańska, Uzasadnione oczekiwania $w$ perspektywie prawa krajowego i regulacji europejskich, Warszawa 2016, s. 138.

39 Wyrok TS z dnia 26 lutego 1987 r. w sprawie 15/85, Consorzio Cooperative d’Abruzzo v. Komisja Wspólnot Europejskich, ECR 1987, s. 01005, ECLI:EU:C:1987:111, pkt 12 i 17. 
towanie lub organizację zintegrowanych rynków ${ }^{40} . Z$ drugiej strony, biorąc pod uwagę złożoność współczesnego prawa administracyjnego, jest wręcz nierealne, aby wymagać od jednostki oceny legalności każdego aktu wydanego przez organy administracji publicznej. Dlatego brak jakiejkolwiek ochrony uzasadnionych oczekiwań może spowodować znaczne trudności i podważyć zaufanie do władzy publicznej ${ }^{41}$. A zatem zmiana lub uchylenie tego rodzaju aktów administracyjnych muszą być poprzedzone wyważeniem interesu publicznego i interesu indywidualnego. W celu ustalenia właściwej równowagi należy wyróżnić pięć kryteriów wartościujących te sprzeczne interesy ${ }^{42}$.

Po pierwsze, od adresata aktu administracyjnego wymaga się należytej staranności w upewnieniu się, czy jest on zgodny z prawem ${ }^{43}$. Innymi słowy, oczekiwania nie zasługują na ochronę, jeżeli adresat aktu administracyjnego wiedział o jego sprzeczności z prawem lub niewiedza o tym wynikała z poważnego niedbalstwa ${ }^{44}$. Po drugie, należy uwzględnić stopień naruszenia prawa ${ }^{45}$. Z jednej strony istotne naruszenie prawa uzasadnia zmianę lub uchylenie aktu administracyjnego. $Z$ drugiej - nieistotne naruszenie europejskiego prawa nie może stanowić podstawy do wzruszenia ostatecznego aktu administracyjnego. Do kwalifikowanych wad można zaliczyć wydanie aktu administracyjnego bez podstawy prawnej, w tym przede wszystkim oparcie decyzji na przepisie, który nie wszedł w życie lub w dacie procedowania utracił moc obowiązującą, ewentualnie na podstawie normy, która nie jest powszechnie obowiązującym źródłem prawa UE. Istotnym naruszeniem europejskiego prawa administracyjnego jest również naruszenie praw podstawowych, a także wydanie aktu administracyjnego z naruszeniem przepisów o właściwości lub w rezultacie błędnej wykładni przepisów prawa będących podstawą decyzji o obowiązkach jednostki. Po trzecie, wyważając sprzeczne interesy, organ administracji unijnej powinien uwzględnić konsekwencje wzruszenia aktu administracyjnego dla jego adresata, w szczególności gdy w oparciu o tego rodzaju rozstrzygnięcie poczynił on definitywne i nieodwracalne inwestycje ${ }^{46}$. Po czwarte, należy zbadać wpływ skasowania lub utrzymania w mocy niezgodnego z prawem aktu administracyjnego na sytuację osób trzecich ${ }^{47}$. W sprawach SNUPAT i Hoogovens

40 P. Craig, EU Administrative law..., s. 562.

41 S. Schonberg, Legitimate expectations..., s. 95.

42 Ibidem, s. 98.

43 Ibidem, s. 98-99.

44 Wyrok Sądu do spraw Służby Publicznej z dnia 11 września 2008 r. w sprawie F-51/07, Philippe Bui Van v. Komisja Wspólnot Europejskich, pkt 55; P. Craig, EU Administrative law..., s. 565.

45 S. Schonberg, Legitimate expectations..., s. 100.

46 Ibidem, s. 99.

47 Ibidem, s. 100. 
Trybunał podkreślił, że interes publiczny UE wymaga, aby unikać sytuacji, gdy niezgodna z prawem decyzja o zwolnieniu z opłat publicznoprawnych prowadzi do uszczerbku dla pozostałych producentów zobowiązanych do płacenia tego rodzaju opłat ${ }^{48}$. Innymi słowy, wyważając sporne interesy, należy zbadać, czy zaniechanie wzruszenia sprzecznego z prawem aktu administracyjnego będzie prowadzić do dyskryminacji pozostałych uczestników obrotu prawnego i naruszenia reguł konkurencji. Po piąte, zmiana lub uchylenie sprzecznego z prawem aktu administracyjnego musi nastąpić w rozsądnym termini ${ }^{49}$. Kryterium rozsądnego terminu nie zostało wprost zdefiniowane w prawie pisanym. Dlatego o tym, czy termin odwołania aktu administracyjnego jest rozsądny, decydują okoliczności konkretnej sprawy, w tym jej kontekst, poszczególne etapy, stopień jej złożoności, a także znaczenie sprawy dla poszczególnych stron sporu i ich zachowanie ${ }^{50}$. Co się zaś tyczy sposobu obliczenia rozsąanego terminu do zamiany lub uchylenia tego rodzaju aktów administracyjnych, to w celu oceny, czy jest on rozsądny, jako punkt wyjścia należy wziąć pod uwagę datę wydania aktu, który administracja zamierza wzruszyćs ${ }^{51}$.

\subsection{Zmiana i uchylenie niekorzystnych dla strony aktów administracyjnych}

Ogólnie rzecz ujmując, ochrona uzasadnionych oczekiwań jednostki odnosi się do aktów administracyjnych, które są korzystne dla strony. Jeżeli zaś chodzi o zmianę lub uchylenie decyzji administracyjnych nakładających jakiekolwiek obowiązki, to zasadniczo nie powstaje tu problem ochrony uzasadnionych oczekiwań jednostki. Zniesienie skutków prawnych takich aktów jest korzystne dla sytuacji prawnej jednostki, skoro po odwołaniu nie spoczywają już na niej jakiekolwiek obowiązki. Zatem niezgodne z prawem akty administracyjne, nakładające obowiązki, mogą być odwołane nawet ze skutkiem wstecznym (ex tunc $)^{52}$.

48 Wyrok TS z dnia 22 marca 1961 r. w sprawach połączonych 42/59 i 49/59, SNUPAT; wyrok TS z dnia 12 lipca 1962 r. w sprawie 14/61, Koninklijke Nederlandsche Hoogovens en Staalfabrieken N.V. v. Wysoka Władza Europejskiej Wspólnoty Węgla i Stali, ECR 1962, s. 00485, s. 270-271, ECLI:EU:C:1962:28.

49 Ibidem.

50 Wyrok Sądu z dnia 10 maja 2006 r. w sprawie T-395/04, Air One SpA v. Komisja Wspólnot Europejskich, ECR 2006, s. II-01343, ECLI:EU:T:2006:123, pkt 61.

51 Wyrok Sądu do spraw Służby Publicznej z dnia 11 września 2008 r. w sprawie F-51/07, Philippe Bui Van v. Komisja Wspólnot Europejskich, pkt 69.

52 J. Schwarze, European administrative law..., s. 1010; M. Jaśkowski, Sądowa kontrola legalności aktów administracyjnych Unii Europejskiej, Warszawa 2016, s. 171-172. 


\section{Model normatywny ReNEUAL}

\subsection{Zmiana i uchylenie zgodnych z prawem korzystnych dla strony aktów administracyjnych}

Zgodnie z art. III-36 ust. 3 modelu przepisów postępowania administracyjnego Unii Europejskiej (dalej model) w ściśle określonych przypadkach dopuszcza się zmianę lub uchylenie zgodnej z prawem decyzji korzystnie wpływającej na sytuację strony. Wzruszenie tego rodzaju decyzji może mieć skutek na przyszłość, natomiast moc wsteczną może mieć jedynie, gdy uchylenie następuje $\mathrm{w}$ rozsądnym terminie (art. III-36 ust. 5 modelu). Tak więc a contrario $\mathrm{z}$ tego przepisu wynika, że organ administracji publicznej mógłby zmienić lub uchylić decyzję korzystnie wpływającą na sytuację strony ze skutkiem na przyszłość w każdym czasie, a nie tylko $\mathrm{w}$ rozsądnym terminie. To rozwiązanie należy ocenić krytycznie z punktu widzenia ochrony uzasadnionych oczekiwań powinna.

Projekt ReNEUAL wychodzi z założenia, że „uchylenie zgodnych z prawem decyzji, które są korzystne, jest szczególnie ważną i delikatną kwestią, z uwagi na zwiększone uzasadnione oczekiwania beneficjentów. Dlatego art. III-36 ust. 3 zd. 3 upoważnia organ administracji publicznej do uchylenia takiej decyzji tylko po spełnieniu bardzo restrykcyjnych warunków" ${ }^{33}$. Zmiana lub uchylenie zgodnej z prawem decyzji korzystnie wpływającej na sytuację strony może nastąpić po upływie przewidzianych prawem terminów wniesienia odwołania:

1) gdy jest to dozwolone prawem UE właściwym dla danego sektora,

2) gdy strona nie wypełniła obowiązku wynikającego $z$ decyzji albo nie uczyniła tego we właściwym terminie,

3) w celu zapobieżenia albo usunięcia poważnej szkody.

W każdym z tych przypadków organ jest obowiązany wziąć pod uwagę wpływ zmiany lub uchylenia na inne strony i osoby trzecie (art. III-36 ust. 4 modelu). Dwie pierwsze przesłanki z art. III-36 ust. 3 są zgodne z modelem teoretycznym. Pewnym novum jest trzecia przesłanka. Twórcy projektu wyjaśnili, że tego rodzaju rozwiązanie jest inspirowane prawem krajowym ${ }^{54}$. Przepis ten pozwala na zmianę lub uchylenie zgodnej z prawem decyzji $\mathrm{z}$ uwagi na poważną szkodę. W komentarzu do modelu precyzuje się, że przesłanka ta dotyczy szkody dla interesu publicznego lub prywatnego, który przeważy nad uzasadnionymi oczekiwaniami beneficjenta. Nie jest jednak jasne, czy chodzi o szkodę dla interesu prawnego czy faktycznego ${ }^{55}$. Wydaje się, że przepis ten należy interpretować w związku z art. III-36 ust. 4 modelu, który stanowi, że organ, wzruszając decyzję, powinien zbadać

53 P. Craig, G. della Cananea, O. Mir, J.-P. Schneider, V.M. Tünsmeyer, M. Wierzbowski, Wydawanie decyzji w sprawach indywidualnych..., s. 142.

54 Ibidem.

55 Ibidem. 
wpływ zmiany lub uchylenia na inne strony albo osoby trzecie. Przepis nie odwołuje się do pojęć sytuacji prawnej lub interesu prawnego. Idzie więc również o interes faktyczny tak zwanej osoby zainteresowanej, a nie tylko strony postępowania, która ma interes prawny rozstrzygnięciu sprawy.

Ciekawym rozwiązaniem jest wprowadzenie kompensacji w przypadku uchylenia lub zmiany decyzji z uwagi na poważną szkodę. Zgodnie $\mathrm{z}$ art. III-36 ust. 3 modelu, w sytuacji gdy zmiana lub uchylenie zgodnej z prawem i korzystnej decyzji następuje w celu zapobieżenia poważnej szkodzie albo jej usunięciu, właściwy organ administracji publicznej na wniosek strony powinien wyrównać negatywne skutki dla strony, wynikające z polegania na trwałości decyzji, jeżeli jest to uzasadnione. Zasadniczo należy pozytywnie ocenić regułę wyrażoną w tym przepisie. Jednym z możliwych rozwiązań dylematu wyważania spornych interesów, tj. uzasadnionych oczekiwań jednostki i zdolności do racjonalnej zmiany polityki administracyjnej, jest przecież naprawienie szkody jednost$\mathrm{ki}^{56}$. Warto przy tym zwrócić uwagę, że zakres kompensacji jest bardzo szeroki. Naprawieniu podlegają bowiem nie tylko straty materialne, lecz również inne niekorzystne skutki poniesione przez adresata aktu administracyjnego. Chodzi zatem o kompensacje strat materialnych (ang. damnum emergens) i utraconych korzyści, które beneficjent aktu mógłby osiągnąć, gdyby nie wzruszono aktu administracyjnego (lucrum cessans $)^{57}$. Ponadto konstrukcja tego przepisu wskazuje, że wzruszenie korzystnej i zgodnej z prawem decyzji administracyjnej w tym przypadku może skutkować zobowiązaniem do naprawienia nie tylko szkody majątkowej, lecz również szkody niemajątkowej ${ }^{58}$. Przepis stanowi o wyrównaniu wszelkich negatywnych skutków zmiany lub uchylenia tego rodzaju aktów administracyjnych. Jednocześnie należy zgłosić wniosek de lege ferenda co do treści art. III-36 ust. 3 modelu. Przepis ten stanowi, że kompensacja szkody nastąpi tylko na wniosek strony. Należy więc wprowadzić regulację zobowiązującą organ, aby w decyzji wydanej na podstawie art. III-36 ust. 3 poinformował i pouczył stronę o prawie do zgłoszenia

56 F.G. Jacobs, Foreword [w:] S. Schonberg, Legitimate expectations...; Ł. Prus, $W$ kwestii ochrony uzasadnionych oczekiwań w prawie administracyjnym UE. Glosa do wyroku TS z dnia 19 maja 1992 r., w sprawach połaczonych C-104/89 oraz C-37/90, „Europejski Przegląd Sądowy” 2012, nr 3, s. 38.

57 Notabene $\mathrm{w}$ orzecznictwie przyjmuje się, że z tytułu naruszenia uzasadnionych oczekiwań jednostce przysługuje prawo do pełnego odszkodowania w granicach szkody majątkowej prawnie relewantnej. A zatem kompensacji podlegają zarówno rzeczywiste straty, jak i utracone korzyści, zob. wyrok TSUE z dnia 19 maja 1992 r. w sprawach połączonych C104/89 i C37/90, Mulder i in. v. Rada Wspólnot Europejskich i Komisja Wspólnot Europejskich, ECR 1992, s. I3061, pkt 32-33.

$58 \mathrm{~W}$ orzecznictwie TSUE znane są przypadki kompensacji szkody niematerialnej w przypadku naruszenia zasady uzasadnionych oczekiwań, zob. wyrok Sądu z dnia 17 grudnia 1998 r. w sprawie T-203/96, Embassy Limousines \& Services v. Parlament Europejski, ECR 1998, s. II-4239, pkt 108. 
wniosku o wyrównanie szkód tym spowodowanych ${ }^{59}$. Ponadto dla pewności prawa warto wprowadzić pewien termin prekluzyjny, w jakim strona może zgłosić tego rodzaju wniosek.

\subsection{Zmiana i uchylenie niezgodnych z prawem korzystnych dla strony aktów administracyjnych}

W modelu przepisów postępowania administracyjnego UE przyjęto, że „w przypadku niezgodnej z prawem decyzji, która jest korzystna, organ administracji może zdecydować o jej uchyleniu albo z mocą wsteczną, albo ze skutkiem na przyszłość, albo wcale (art. III-36 ust. 2). Ten zestaw różnych działań umożliwia zachowanie równowagi pomiędzy interesem publicznym a interesem beneficjenta" 60 .

Zgodnie z art. III-36 ust. 5 zmiana lub uchylenie może mieć moc wsteczną, gdy następuje w rozsądnym terminie, co należy poddać krytyce z tych samych powodów, co w przypadku wzruszenia zgodnych z prawem decyzji. Powyższe zastrzeżenie jest tym bardziej zasadne, że zgodnie z art. III-36 ust. 2 lit. b modelu to uzasadnione oczekiwania beneficjenta aktu przesądzają o tym, czy zmiana lub uchylenie niezgodnej z prawem decyzji powinna nastąpić z mocą wsteczną, czy też ma wywołać skutek na przyszłość.

Jednakże pozytywnie należy ocenić przesłanki zmiany lub uchylenia niezgodnych $\mathrm{z}$ prawem decyzji. Zgodnie $\mathrm{z}$ art. III-36 ust. 2 modelu organ administracji publicznej, wykonując kompetencje w zakresie zmiany lub uchylenia niezgodnych z prawem decyzji korzystnie wpływających na sytuację strony, bierze pod uwagę to, $\mathrm{w}$ jakim stopniu strona mogła w sposób uzasadniony oczekiwać, że decyzja była zgodna z prawem i w jakim stopniu strona polegała na tym. A zatem wzruszenie niezgodnych z prawem decyzji administracyjnych zależy od wyważenia interesu publicznego i indywidualnego. Organ bierze bowiem pod uwagę z jednej strony interes publiczny wyrażający się w zasadzie legalności działania organów administracji unijnej, a $\mathrm{z}$ drugiej strony uzasadnione oczekiwania jednostki co do trwałości sytuacji prawnej (art. III-36 ust. 2). Model normatywny expressis verbis nie precyzuje kryteriów wartościujących te sprzeczne interesy. Jednakże w objaśnieniu do modelu przyjmuje się, że kryteriami pozwalającymi zachować równowagę między interesem publicznym $\mathrm{i}$ indywidualnym są ,stopień przyczynienia się beneficjenta do wydania wadliwej decyzji na skutek przedstawienia organowi nieprawdziwych bądź też niepełnych informacji oraz zakres poniesionych przez niego nieodwracalnych nakładów inwestycyjnych" ${ }^{61}$. Ponadto zgodnie $\mathrm{z}$ art. III-36 ust. 4 wyważając sporne interesy, należy wziąć pod uwa-

59 Przepis $\mathrm{z}$ art. III-30 regulujący obowiązki informacyjne organu nie wprowadza takiego wymogu.

60 P. Craig, G. della Cananea, O. Mir, J.-P. Schneider, V.M. Tünsmeyer, M. Wierzbowski, Wydawanie decyzji w sprawach indywidualnych..., s. 141.

61 Ibidem, s. 142. 
gę wpływ wyruszenia decyzji na inne strony i osoby trzecie. Twórcy modelu zakładają zatem trzy kryteria wartościujące sporne interesy. Warto zatem przypomnieć, że w modelu teoretycznym wyodrębniono pięć kryteriów wartościujących interes publiczny i prywatny w wzruszeniu tego rodzaju aktów, a to kryteria: należytej staranności, stopnia naruszenia prawa, konsekwencji wzruszenia aktu administracyjnego dla jego adresata, wpływu wzruszenia na sytuację osób trzecich i zachowania rozsądnego terminu. Dlatego w tym zakresie należy postulować, aby w modelu normatywnym poszerzyć kryteria oceny niezgodności z prawem aktów administracyjnych o kryterium stopnia naruszenia prawa i rozsądnego terminu.

Trzeba też zwrócić uwagę, że w modelu normatywnym takie okoliczności jak podanie nieprawdziwych lub niepełnych informacji mogą przesądzić o nielegalności aktu administracyjnego, podczas gdy w modelu teoretycznym te okoliczności analizowane są w kontekście wzruszenia zgodnych z prawem aktów. Należy opowiedzieć się za rozwiązaniem przyjętym w modelu normatywnym, jednocześnie postulując, aby doprecyzować, że przede wszystkim umyślne (celowe) przedstawienie organowi nieprawdziwych bądź też niepełnych informacji może przesądzać o wzruszeniu decyzji administracyjnej.

Istotne jest również, że model normatywny wprowadza pewną standaryzację poprzez wprowadzenie jednolitej przesłanki - wyważenia interesów - niezależnie od tego, czy chodzi o zmianę lub uchylenie ze skutkiem ex tunc czy ex nunc. Tak więc przed uchyleniem niezgodnej z prawem decyzji korzystnie wpływającej na sytuację strony ze skutkiem na przyszłość organ administracji unijnej powinien wyważyć sporne interesy. W tym miejscu należy przypomnieć, że w orzecznictwie ugruntowany jest pogląd, że zmiana lub uchylenie ze skutkiem ex nunc niezgodnego z prawem aktu administracyjnego korzystnego dla strony nie podlega żadnym rygorom i jest zawsze możliwa. Tak więc należy zakładać, że model normatywny przede wszystkim jako restatements, czyli model przepisów (zestaw najlepszych praktyk) będzie miał wpływ na linię orzeczniczą i zapoczątkuje sformułowanie nowych reguł kontroli sądowej zmiany lub uchylenia niezgodnych z prawem korzystnych aktów administracyjnych ze skutkiem ex nunc ${ }^{62}$.

\subsection{Zmiana i uchylenie niekorzystnych dla strony aktów administracyjnych}

Model normatywny uzależnia skutek temporalny wzruszenia niekorzystnych dla strony decyzji administracyjnych od stopnia ich legalności. I tak wzruszenie niekorzystnych oraz niezgodnych z prawem aktów admi-

62 O funkcjach i roli restatements, zob. J. Supernat, Restatements - koncepcja i zastosowanie [w:] Administracja pod rzadami prawa. Ksiega pamiatkowa $z$ okazji 70-lecia urodzin prof. $z w$ dra hab. A. Błasia, J. Korczak (red.), Wrocław 2016, s. 455-462; G.B. Bermann, A restatement of European administrative law: problems and prospects [w:] Comparative administrative law, S. Rose-Ackerman, P.L. Lindseth (eds.), Cheltenham 2010, s. 596-599. 
nistracyjnych ma skutek retroaktywny, a decyzji niekorzystnych i zgodnych $\mathrm{z}$ prawem moc prospektywną. Zgodnie z art. III-35 ust. 1 modelu organ administracji unijnej może zmienić lub uchylić niezgodną z prawem decyzję niekorzystnie wpływającą na sytuację strony. Taka zmiana albo uchylenie niezgodnego z prawem aktu administracyjnego zawsze ma skutek wsteczny (ex tunc). Innymi słowy, niekorzystny dla strony skutek prawny powinien być zniesiony $\mathrm{z}$ mocą wsteczną, tj. od chwili wejścia do obrotu prawnego pierwotnej decyzji. Stosownie zaś do treści art. III-35 ust. 2 modelu organ administracji publicznej może zmienić lub uchylić zgodną z prawem decyzję niekorzystną wpływającą na sytuację prawną strony, przy czym taka zmiana lub uchylenie wywołują skutki na przyszłość (ex nunc).

Niezależnie od tego, czy zmiana lub uchylenie dotyczy zgodnej czy niezgodnej z prawem decyzji niekorzystnej, zawsze organ administracji publicznej wykonując te kompetencje, bierze pod uwagę wpływ zmiany lub uchylenia na inne strony oraz osoby trzecie (art. III-35 ust. 4). We wczesnym orzecznictwie Trybunału pewne problemy stwarzały sprzeczne z prawem akty administracyjne o charakterze podwójnym. Chodzi o taką sytuację, w której z jednej strony akt administracyjny przyznawał korzyści konkretnemu przedsiębiorcy, a $\mathrm{z}$ drugiej strony nakładał obowiązki na innego. W takim przypadku Trybunał w pierwszej kolejności badał zasadność wzruszenia z punktu widzenia strony, dla której akt administracyjny był korzystny. W tym zakresie należało wyważyć interes publiczny oraz indywidualny i jeżeli ten pierwszy przeważał za odwołaniem korzyści dla jednej ze stron, to zasadne było odwołanie obciążeń dla drugiej strony ${ }^{63}$. $\mathrm{W}$ tym kierunku zmierzają uregulowania przyjęte $\mathrm{w}$ modelu normatywnym, przy czym wprowadzają też szerszą kategorię. Organ ma obowiązek badać nie tylko interes prawny podmiotów innych niż beneficjent aktu, lecz również ogólny wpływ (a zatem interes faktyczny) zmiany lub uchylenia na inne strony oraz osoby trzecie.

\section{Uwagi końcowe}

Z powyższego porównania wynika, że opracowany przez sieć naukowo-badawczą ReNEUAL model przepisów procedury dla administracji Unii Europejskiej stanowi doskonałą syntezę dotychczasowego doświadczeń prawnych. A zatem jako restatements może pozytywnie oddziaływać na przestrzeń prawną Unii Europejskiej. Model normatywny w zakresie szczególnego trybu wzruszania ostatecznych aktów administracyjnych w dużej mierze jest zgody z modelem teoretycznym i systematyzuje dotychczasowy dorobek orzeczniczy Trybunału. Istotny jest również fakt, że model norma-

63 Wyrok TS z dnia 22 marca 1961 r. w sprawach połączonych 42/59 i 49/59, SNUPAT; J. Schwarze, European administrative law..., s. 1010; J. Raitio, The principle of legal certainty..., s. 237-238. 
tywny nie tylko porządkuje rozproszone case law i regulacje prawa sektorowego, lecz uwzględnia także postulaty nauki, choćby w zakresie ujednolicenia zasad wzruszenia niezgodnych z prawem aktów administracyjnych ze skutkiem ex nunc i ex tunc. Należy też odnotować, że model normatywny wprowadza innowacyjne rozwiązania prawne poprzez uregulowanie mechanizmu kompensacji szkody jednostki, który równoważy potrzebę racjonalnej zmiany polityki administracyjnej i ochrony uzasadnionych oczekiwań. Jednakże w modelu normatywnym zaskakuje brak zgody adresata na wzruszenie decyzji jako przesłanki zmiany lub uchylenia zgodnych z prawem decyzji. Ponadto warto, aby model normatywny uwzględnił wszystkie pięć kryteriów umożliwiających wyważenie interesu publicznego i prywatnego przy wzruszeniu niezgodnych z prawem decyzji administracyjnych. Przedstawione uwagi i postulaty de lege ferenda nie zmieniają jednak pozytywnej oceny modelu postępowania administracyjnego Unii Europejskiej.

\section{Bibliografia}

Baran M., Zmiana i uchylenie decyzji: dotychczasowa praktyka a propozycje zawarte w modelu kodeksu postępowania administracyjnego Unii Europejskiej (wybrane problemy) [w:] Kodeks postępowania administracji Unii Europejskiej, J. Supernat, B. Kowalczyk (red.), Warszawa 2017.

Bermann G.B., A restatement of European administrative law: problems and prospects [w:] Comparative administrative law, S. Rose-Ackerman, P.L. Lindseth (eds.), Cheltenham 2010.

Craig P., EU administrative law, Oxford 2012.

Craig P., della Cananea G., Mir O., Schneider J.-P., Tünsmeyer V.M., Wierzbowski M., Wydawanie decyzji w sprawach indywidualnych [w:] ReNEUAL. Model kodeksu postępowania administracyjnego Unii Europejskiej, M. Wierzbowski, H.C.H. Hofmann, J.-P. Schneider, J. Ziller (red.), M. Wierzbowski (red. wyd. polskiego), A. Kraczkowski, tłum. M. Ziental, P. Dorobek, Warszawa 2015.

Hofmann H.C.H., Rowe G.C., Türk A.H., Administrative law and policy of the EU, Oxford 2011.

Jaśkowski M., Sąowa kontrola legalności aktów administracyjnych Unii Europejskiej, Warszawa 2016.

Kamiński M., Zmiana i uchylenie decyzji niewadliwych i wadliwych w świetle założeń modelu kodeksu postępowania administracyjnego Unii Europejskiej. Uwagi na tle niemieckiej federalnej ustawy o postępowaniu administracyjnym [w:] Kodeks postępowania administracji Unii Europejskiej, J. Supernat, B. Kowalczyk (red.), Warszawa 2017.

Kledzik P., Weryfikacja aktów administracyjnych według założeń modelu kodeksu postępowania administracyjnego Unii Europejskiej w kontekście uregulowań kodeksu postępowania administracyjnego [w:] Kodeks postępowania administracji Unii Europejskiej, J. Supernat, B. Kowalczyk (red.), Warszawa 2017.

Lemańska J., Uzasadnione oczekiwania $w$ perspektywie prawa krajowego i regulacji europejskich, Warszawa 2016. 
Lonchamps F., Z badań porównawczych $w$ dziedzinie prawa. Refleksja metodologiczna, „Acta Universitatis Wratislaviensis”, No 125, Prawo XXXII, Wrocław 1970.

Niedźwiedź M., Administracyjne wykonywanie prawa Unii Europejskiej [w:] System Prawa Administracyjnego, t. 3, Europeizacja prawa administracyjnego, R. Hauser, Z. Niewiadomski, A. Wróbel (red.), Warszawa 2014.

Prus Ł., W kwestii ochrony uzasadnionych oczekiwań $w$ prawie administracyjnym UE. Glosa do wyroku TS z dnia 19 maja 1992 r., w sprawach połaczonych C-104/89 oraz C-37/90, „Europejski Przegląd Sądowy” 2012, nr 3.

Prus Ł., Zasada pewności i ochrony uzasadnionych oczekiwań [w:] Prawo administracyjne Unii Europejskiej, R. Grzeszczak, A. Szczerba-Zawada (red.), Warszawa 2016.

Ratio J., The principle of legal certainty in EC law, Dordrecht/Boston/London 2003.

Rączka P., Jędrzejewski T., Zmiana i uchylenie decyzji w modelu kodeksu postępowania administracyjnego Unii Europejskiej w kontekście polskich doświadczeń [w:] Kodeks postępowania administracji Unii Europejskiej, J. Supernat, B. Kowalczyk (red.), Warszawa 2017.

Schneider J.-P., The ReNEUAL codification project - book III [w:] The model rules on EU administrative procedures: adjudication, M. Ruffert (ed.), Groningen 2016.

Schonberg S., Legitimate expectations in administrative law, Oxford 2003.

Schwarze J., European administrative law, Luxemburg 1992.

Supernat J., Restatements - koncepcja i zastosowanie [w:] Administracja pod rzadami prawa. Ksiegga pamiątkowa $z$ okazji 70-lecia urodzin prof. $z w$ dra hab. A. Błasia, J. Korczak (red.), Wrocław 2016.

Streszczenie

Celem artykułu jest porównanie modelu teoretycznego i normatywnego zmiany lub uchylenia aktów administracyjnych organów administracji unijnej. W prawie pisanym UE brak jest uniwersalnych reguł dotyczących tej kwestii. Z jednej strony problematykę tę regulują zasady wypracowane przez relewantne orzecznictwo Trybunału Sprawiedliwości Unii Europejskiej, które nie są wynikiem działań legislacyjnych, co wymaga rekonstrukcji i systematyzacji elementów istotnych dla zasad wzruszenia aktów administracyjnych wynikających z kazuistycznego prawa sędziowskiego TSUE. W ten sposób można wypracować model teoretyczny zmiany lub uchylenia aktów administracyjnych UE. Z drugiej strony ten problem reguluje model normatywny przyjęty w modelu postępowania administracyjnego UE opracowanym przez sieć naukowo-badawczą do spraw prawa administracyjnego UE (ReNEUAL). Artykuł zawiera autorski komentarz co do propozycji grupy ReNEUAL w tym zakresie.

Słowa kluczowe: wzruszenie aktów administracyjnych UE, uzasadnione oczekiwania, postępowanie administracyjne Unii Europejskiej 


\section{Amending and Repealing of Administrative Acts Issued by EU Institutions: Theoretical and Normative Models \\ Abstract}

The article aims to compare the theoretical and normative models of amending or repealing of acts issued by EU administrative bodies. EU written law lacks universal principles governing the issue. On the one hand, it is regulated by the rules stemming from relevant case law of the Court of Justice of the European Union, which are not products of legislative work. EU law also required reconstruction and systematisation of aspects that are vital for the principles of overturning administrative acts resulting from casuistic judge-made law of the CJEU. In this way, it is possible to work out a theoretical model of amending or repealing of EU acts. On the other hand, the issue is regulated by the normative model adopted in the model of EU administrative proceedings developed by the Research Network on EU Administrative Law (ReNEUAL). The article includes the author's comments as regards the proposal offered by ReNEUAL in this area.

Keywords: overturning of EU administrative acts, justified expectations, administrative proceedings of the European Union 